Table 1. EFFECTS OF ALLOXAN DIABETES, STARVATION AND REFEEDING ON THE ACTIVITIES OF HEXOKINASE, PHOSPHOFRUCTOKINASE, PYRUVATE KINASE

Experiment

Control rats, normal diet Alloxan diabetic rats, normal diet Control rats, powdered normal diet 3-day starved rats Control rats, powdered high carbohydrate diet ( 3 days)

Starved rats, refed powdered high carbohydrate diet ( 3 days)

Conditions of diet and

Civen in the text. AND ALDOLASE IN RAT EPIDIDYMAL ADIPOSE TISSUE Hexokinase mean \pm standard error $\mathrm{mu} / \mathrm{fat} \mathrm{mu} / \mathrm{mg}$ of pad pair protein $150 \pm 12 \quad 23 \cdot 5 \pm 2 \cdot 4$
$93 \pm 4^{*} \quad 13 \cdot 6 \pm 1 \cdot 3 *$ $126 \pm 10 \quad 18 \cdot 0 \pm 1 \cdot 8$ $\begin{array}{rr}126 \pm 10 & 18 \cdot 0 \pm 1 \cdot 8 \\ 78 \pm 9 * & 9 \cdot 7 \pm 0.9 *\end{array}$ $206 \pm 13 \quad 21.9 \pm 1 \cdot 7$ $19 \cdot 8 \pm 2 \cdot 2 \quad 261 \pm 22$ Phosphofrud (n) mulf \pm standard error mu/fat mu/mg of pad pair protein Pyruvate kinase mean \pm standard error $\mathrm{mu} / \mathrm{fat} \mathrm{mu} / \mathrm{mg}$ o pad pair protein $141 \pm 12 \quad 21 \cdot 6 \pm 1 \cdot 5$ $17 \cdot 9 \pm 1 \cdot 1$ $212 \pm 23$ $470 \pm 45$
$454 \pm 32$ $3,220 \pm 202$ $3,220 \pm 202$
$3,644 \pm 293$ $23 \cdot 5 \pm 1 \cdot 9$ $30 \cdot 0 \pm 1 \cdot 9 \quad 6,322 \pm 633$ $663 \pm 62$

$29 \cdot 0 \pm 2 \cdot 5 \quad 5,755 \pm 555 \quad 643 \pm 66$ compare with maximum uptakes of glucose in fat pads from rats fed normally on approximately $10 \mathrm{~m}$ umoles $/ \mathrm{mg}$ protein/min, as calculated from known data ${ }^{14}$. Total $\mathrm{HK}$ activity is decreased approximately 40 per cent in alloxandiabetes and starvation. These figures are in close agreement with previously published data ${ }^{7,8}$. In contrast to the changes in HK, levels of PFK, PK and aldolase are not depressed to any statistically significant extent. Refeeding after starvation restores HK activities to control values in experimental animals. The levels of both HK and PK in the controls fed the high carbohydrate diet are markedly increased over those of the controls on the normal diet, while smaller changes are apparent in PFK and aldolase activities. The physiological importance of the changes in HK activity in epididymal fat pad have been considered previously ${ }^{75}$. Ballard et al. ${ }^{16}$ have recently reported the occurrence of phosphoenolpyruvate carboxykinase in this tissue, and have demonstrated the conversion of pyruvate to glyceride-glycerol through the dicarboxylate shuttle. It is most probable therefore that PK has a regulatory role in determining the fate of phosphoenolpyruvate in fat pad. The changes observed with high carbohydrate diet are consistent with this hypothesis, and may thus be of some physiological significance.

We thank the British Diabetic Association and the Medical Research Council for grants.

Department of Biochemistry,

C. I. Pogson

R. M. DEnToN

University of Bristol.

Received July 31, 1967.

${ }^{1}$ Weber, G., Stamm, N. B., and Fisher, E. A., Science, 149, 65 (1965).

2 Weber, G., and Singhal, R. L., Life Sci., 4, 1993 (1965).

s Sharma, C., Manjeshwar, R., and Weinhouse, S., Adv. in Enzyme Regulation, 2,189 (1964).

4 Weber, G., Singhal, R. I., Stamm, N. B., Lea, M. A., and Fisher, E. A., Adv. in Enzyme Regulation, 4, 59 (1966). ${ }^{5}$ Randle, P. J., Garland, P. B., Hales, C. N., Newsholme, E. A., Denton,
R. M., and Pogson, C. I., Rec. Prog. Hormone Res., 22, 1 (1966).

6 Pogson, C. I., and Randle, P. J., Nature, 212, 1053 (1966).

${ }^{7}$ McLean, P., Brown, J., Greenslade. K., and Brew, K., Biochem. Biophys. Res. Commun., 23, 117 (1966)

- Moore, R. O., Chandler, A. M., and Tettenhorst, N., Biochem. Biophys. Res, Commun., 17, 527 (1964).

${ }^{9}$ Denton, R. M., and Randle, P. J., Biochem. J., 100, 420 (1966).

${ }^{10}$ Denton, R. M., Yorke, R. E., and Randle, P. J., Biochem. J., 100, 407 (1966).

11 Pogson, C. I., and Randle, P. J., Biochem. J., 100, 683 (1966)

12 Newsholme, E. A., and Randle, P. J., Biochem. J., 80, 655 (1961).

is Lowry, O. H., Rosebrough, N. J., Farr, A. I., and Randall, R. J., J. Biol. Chem. 193, 265 (1951).

${ }^{14}$ Denton, R. M., and Randle, P. J., Biochem. J., 104, 423 (1967).

ss Katzen, H. M., and Schimke, R. T., Proc. US Nat. Acad. Sci., 54, 1218 (1965). ${ }^{16}$ Ballard, F. J., Hanson, R. W., and Leveille, G. A., J. Biol. Chem., 242,
2746 (1967).

\section{Fatty Acid Ester-Hydrocarbon Correlation Trial: a Comment}

DuriNG the sixth International Symposium on Gas Chromatography in Rome Ro $^{1}$ Dr P. A. T. Swoboda, on behalf of the Data Sub-committee of the Gas Chromatography Discussion Group, presented a preliminary report on an inter-laboratory trial on the reproducibility of retention data, which gave the following conclusion: " . . the use of the carbon number scale leads to a high degree of agreement between laboratories for the methylesters of unsaturated fatty acids. In contrast there is a wide variation for the hydrocarbons. Thus the use of a secondary series of standards (such as the methylesters of the $n$-alkanoic acids) as the basis for a logarithmic scale of retention gives a higher inter-laboratory precision for measurement of compounds of similar structure than would be obtained by using the Retention Index based on the $n$-alkanes"

In my opinion the data presented do not justify this conclusion. Only esters have been compared with hydrocarbons and extension of the generalization to other classes of compounds does not seem justified without more data.

Another point to be considered is the stationary phase used (polyethylene glycol adipate, PEGA). Each participant used his own batch of PEGA and the reporter observed that the results of participants whose PEGA was either too polar or too apolar were not included in the analysis. Moreover, no mention is made of the amount of stationary phase nor of the support used. I feel that this indicates that different batches of PEGA differed in polarity or at least that the total columnpackings differed in polarity. Furthermore, PEGA is also an ester and hence similar to the compounds chromatographed.

In my opinion, the wide range of carbon numbers, as displayed by the $n$-alkanes, reflects the differences in polarity between the column-packings, this reflexion being less for the esters because of the similarity between the solutes and solvent (PEGA).

I should also like to comment on the way the carbon numbers were calculated. It is formally stated that "the algebraic equation defining the scale is the same as that used for the calculation of Retention Index". For the calculations, however, a straight line was fitted statistically instead of using the actual measurements. In the case of the $n$-20-alkane even extrapolation was used. This method of calculation introduces an error unnecessarily. Although the statistical procedure permits confidence limits to be drawn, no such limits are mentioned. In view of the fact that in the equation given in the report, both constants are related, I believe that in fact $r_{x, 17}$ values, not carbon numbers, were determined.

Apart from the comment on the calculation, my principal point is that there is a need for some kind of character. ization of columns with respect to "polarity", especially in trials of this kind.

\section{H. VAN DEN DOOL}

IFF (Nederland) NV,

Hilversum,

The Netherlands.

Received July 31, 1967.

${ }^{1}$ Sixth Intern. Symp. Gas Chromatog., Rome 1966 (edit. by Littlewood, A. B.) (1967). 